\title{
Spontaneous pneumothorax secondary to granulomatous pneumonia caused by Angiostrongylus vasorum in a dog in Denmark
}

Spodsberg, Eva-Maria Hohneck; Miles, James Edward; McEvoy, Fintan; Willesen, Jakob

Published in:

Journal of Small Animal Practice

DOI:

10.1111/jsap. 12023

Publication date:

2013

Document version

Early version, also known as pre-print

Citation for published version (APA):

Spodsberg, E-M. H., Miles, J. E., McEvoy, F., \& Willesen, J. (2013). Spontaneous pneumothorax secondary to granulomatous pneumonia caused by Angiostrongylus vasorum in a dog in Denmark. Journal of Small Animal Practice, 54(2), 114. https://doi.org/10.1111/jsap.12023 


\section{Spontaneous pneumothorax secondary to granulomatous pneumonia caused by Angiostrongylus vasorum in a dog in Denmark}

- A case report

EVA-MARIA HOHNECK-SPODSBERG, JAMES EDWARD MILES, FINTAN MCEVOY OG JAKOB WILLESEN
UNIVERSITY HOSPITAL FOR COMPANION ANIMALS, DEPARTMENT OFVETERINARY CLINICAL AND ANIMALSCIENCES,
FACULTY OF HEALTH AND MEDICAL SCIENCES, UNIVERSITY OF COPENHAGEN, DENMARK

\section{Summary}

Granulomatous pneumonia secondary to Angiostrongylus vasorum was diagnosed in a dog presenting with bilateral pneumothorax. A 2-year-old, female, intact Whippet presented to the University Hospital for Companion Animals at the University of Copenhagen with an acute history of progressing dyspnoea, exercise intolerance and anorexia. On thoracocentesis, $760 \mathrm{ml}$ air was evacuated from the left hemithorax while $7200 \mathrm{ml}$ air was emptied from the right hemithorax without achieving a vacuum on this side. Thoracic radiographs revealed a gas-filled bulla in the right caudal lung lobe with marked bilateral lobar collapse in addition to a bilateral pneumothorax. Thoracic CT examination confirmed pulmonary consolidation, collapse and a bulla in the caudal part of the right caudal lung lobe. On lobectomy of the right caudal lung lobe, consolidated, granuloma-like lung tissue was identified. Histological examination revealed numerous, often coalescing, granulomata centred on parasitic $A$. vasorum larvae and eggs in the collapsed and fibrotic lung parenchyma. Faecal samples were positive for $A$. vasorum L1-larvae, and the dog was treated with fenbendazole for 20 days. The dog made a full recovery.

\section{Sammendrag}

En hund med bilateral pneumothorax blev diagnosticeret med en granulomatøs pneumoni forårsaget af Angiostrongylus vasorum. En 2 år gammel, intakt Whippet tæve blev præsenteret med akut, progressiv dyspnø, motionsintolerance og anoreksi. Ved thoracocentese blev 760 ml luft evakueret fra venstre hemithorax og 7200 ml luft fra højre hemithorax uden at et vakuum kunne opnås på denne side. Røntgenbilleder fra thorax viste en gas-fyldt bulla i den højre kaudale lungelobus med udtalt bilateral lungelobi kollaps samt bilateral pneumothorax. CT undersøgelsen af thorax bekræftede lungekonsolidering, kollaps og en bulla in den kaudale del af den højre kaudale lungelobus. Ved lobektomi af den højre kaudale lungelobus blev konsolideret, granulom-lignende væv fundet. Histologisk undersøgelse viste talrige granulomata med $A$. vasorum larvae og æg i kollaberet og fibrotisk lungeparenkym. Afføringsprøver (Baermann) viste A. vasorum L1-larvae, og hunden blev behandlet med fenbendazol for 20 dage. Hunden blev klinisk rask.

\section{Introduction}

Canine pulmonary angiostrongylosis is caused by the metastrongyloid nematode Angiostrongylus (A.) vasorum (1).

Angiostrongylosis occurs worldwide with endemic foci in Europe in the UK, Ireland, Denmark and France $(2,3,4,5,6)$. $A$. vasorum has an indirect life cycle with a definitive host in dogs and related canidae. Adult worms reside in the pulmonary arteries within the definitive host and, after hatching of eggs shed by the female worms, the first-stage larvae (L1-larvae) migrate from the capillaries through the pulmonary parenchyma and into the smaller airways. Hence, the most commonly reported clinical signs are related to the respiratory tract and include coughing, exercise intolerance and dyspnoea, although many other clinical signs associated with $A$. vasorum infections have been reported $(4,6)$. These include haemorrhagic diathesis of the lungs, brain, eyes, skin or abdomen $(4,7,8,9)$ and haemothorax and haemoabdomen $(10,8)$. Pneumothorax has been mentioned in association with angiostrongylosis (11), but has not been described in detail so far.

Pneumothorax can be seen secondary to trauma or spontaneously with emphysematous bullae, neoplasia, lung lobe necrosis and parasitic infections such as Filaroides osleri (12) or Dirofilaria immitis > 


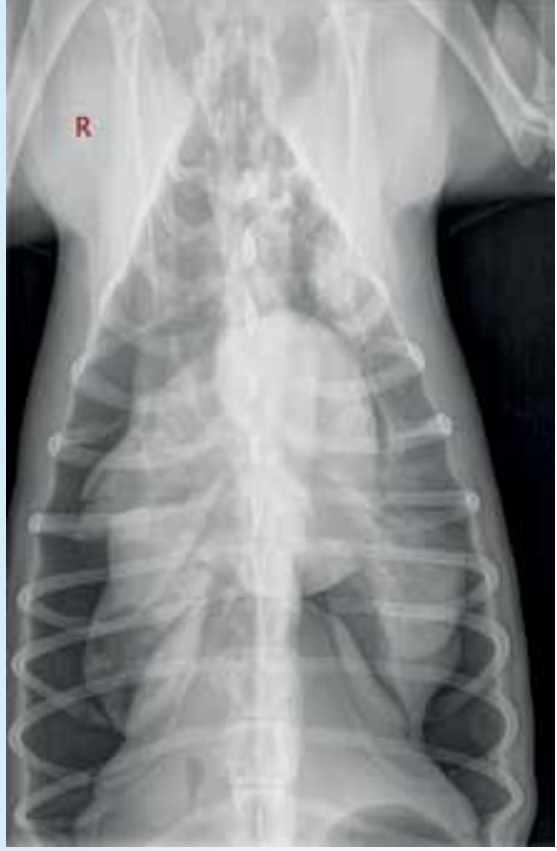

Figure 1. Dorso-ventral thoracic radiographs. There is bilateral pneumothorax with collapse of all lung lobes. In the periphery of the right caudal lobe, there is a roughly circular radioluscent zone, interpreted as a pulmonary bulla.

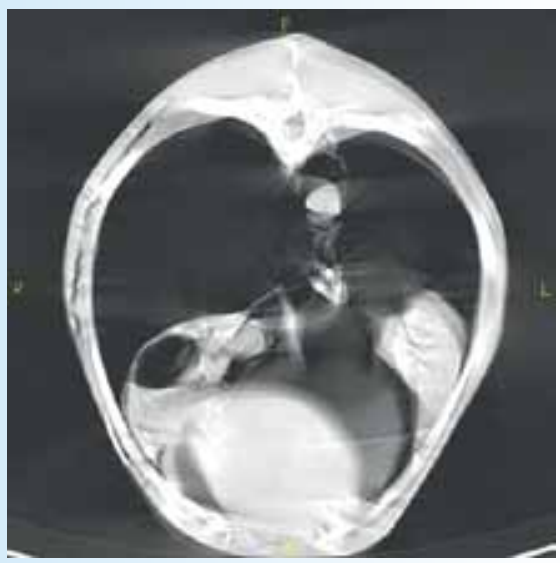

Figure 2. A transverse $\mathrm{CT}$ of the caudal thorax displayed in a lung window (with $1600 \mathrm{HU}$, center $-600 \mathrm{HU}$ ). Slice thickness: $5 \mathrm{~mm}$.

Patients ${ }^{-}$right side is to the left of the image. The pleural and mediastinal space is gas-filled. The lungs are markedly collapsed and consolidated. Some subcutaneous emphysema is seen in the right thoracic wall (due to previous thoracocentesis). A large bulla ( $3 \mathrm{~cm}$ in diameter) is seen in the caudal part of the right caudal lung lobe.
(13). Recently, pulmonary thromboembolism was identified as the cause of spontaneous pneumothorax in a dog with pituitary-dependent hyperadrenocorticism (14). Identification of the underlying cause is important for the prognosis and treatment of pneumothorax.

\section{Case History}

A 2-year-old, female, intact Whippet presented to the University Hospital for Companion Animals at the University of Copenhagen with a 2-days history of rapidly progressing dyspnoea, exercise intolerance and anorexia. The dog was current on vaccinations, had no travel history outside Denmark and had not been wormed for the last 12 months. It lived in a multi-dog household in a rural environment and none of the other dogs (all Whippets) were reported to show signs of illness.

Physical examination confirmed tachypnoea (respiratory rate 80 breaths/minute), a severly increased, mainly expiratory, respiratory effort, bilaterally muffled dorsal lung sounds and increased ventral lung sounds.

On thoracocentesis, $760 \mathrm{ml}$ air was evacuated from the left hemithorax while $7200 \mathrm{ml}$ air was emptied from the right hemithorax without achieving a vacuum on this side. Nonetheless the dog's condition improved and the respiratory rate decreased to 40 breaths/minute. Thoracic radiography and ultrasound, a complete blood count, serum biochemistry, urinalysis and a faecal analysis (collected rectally for a direct faecal examination) were performed.

On thoracic radiographs, a gas-filled bulla in the right caudal lung lobe and marked bilateral lobar collapse was seen in addition to a bilateral pneumothorax (Figure 1). With no history of trauma or oesophageal foreign body, spontaneous pneumothorax with ongoing leakage of air into the right pleural space was suspected. Echocardiography revealed no signs of primary cardiac involvement. No larvae were found on the direct faecal smear (15). Mature neutrophilia $\left(15 \cdot 37 \times 10^{9} /\right.$, reference limits $3 \cdot 2$ to
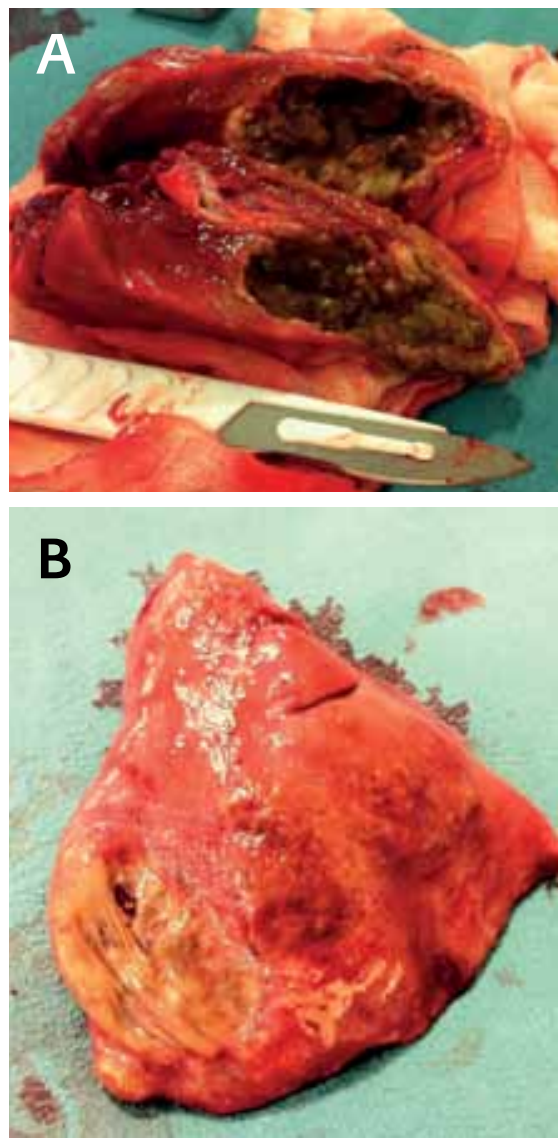

Figure 3. A segment of the removed lung lobe. A: The region associated with the bulla is seen as flattened, yellowish surface which was found to contain a discrete tear. B: Lung tissue under the surface was macroscopically highly abnormal.

$\left.12 \cdot 1 \times 10^{9} / \mathrm{I}\right)$ and mild hyperfibrinogenaemia $(4.61 \mathrm{~g} / \mathrm{L}$, reference limits 1 to 4 $\mathrm{g} / \mathrm{L}$ ) were the only other abnormalities.

Under general anaesthesia, a 14-gauge small-bore wire-guided chest drain (MILA Chest Drain; MILA International Inc.) was placed in the right hemithorax using a modified Seldinger technique and continuous drainage instituted. Subsequent CT examination of the thorax confirmed pulmonary consolidation, collapse and a bulla ( $3 \mathrm{~cm}$ in diameter) in the caudal part of the right caudal lung lobe (Figure 2). No other potential causes of pneumothorax were identified.

On right intercostal thoracotomy, continuous air leakage was observed from the area of the bulla. The region comprised consolidated, granuloma-like lung tissue which was removed by lobectomy 
using a stapling device (Proximate Linear Stapler TX60B, Ethicon) (Figure 3).

Radiographs on day 2 showed almost completely inflated lungs, and the chest tube was removed as no air could be evacuated. Analgesia was provided with methadone (Metadon $10 \mathrm{mg} / \mathrm{ml}$,

Nycomed Danmark) as needed, combined with a transdermal fentanyl patch (Durogesic $50 \mathrm{mcg} / \mathrm{h}$, Janssen-Cilag), and supplemented with a lidocaine infusion (Xylocain $10 \mathrm{mg} / \mathrm{ml}$, AstraZeneca) for the first 24 hours. Faecal samples for Baermann analysis collected during postoperative hospitalisation were positive for $A$. vasorum L1-larvae, and treatment with the antiparasitic agent fenbendazole in a dosage of $25 \mathrm{mg} / \mathrm{kg}$ SID orally for 20 days (Panacur vet. $500 \mathrm{mg}$, Intervet) was started (16). Bacteriological and mycological culture of lung tissue was sterile. Histological examination of the necrotic lesion revealed numerous, often coalescing, granulomata centred on parasitic $A$. vasorum larvae and eggs in the collapsed and fibrotic lung parenchyma and irregular muscular hypertrophy of the larger pulmonary vessels giving a diagnosis of chronic granulomatous pneumonia due to A. vasorum infection (Figure 4).

On day 3 the dog was bright and alert without respiratory signs and was discharged with instructions to complete fenbendazole treatment and to keep the dog at rest. A follow-up examination was performed on day 21. Clinical examination, haematology, biochemistry and thoracic radiographs did not reveal any abnormalities. No larvae were found on Baermann analysis. The owner reported that all other dogs in the household had been subsequently diagnosed with $A$. vasorum infection on Baermann analysis and treatment with fenbendazole had been initiated. The owner was instructed to provide monthly A.vasorum prophylaxis with moxidectin $2.5 \%$ / imidacloprid $10 \%$ spot-on solution (Advocate, Bayer) for all dogs according to their body weight. The dog made a full recovery.

\section{Discussion}

This dog presented with a spontaneous pneumothorax which had developed secondary to a single ruptured granulomatous lung lesion, ultimately caused by $A$. vasorum, indicating that canine angiostrongylosis should be considered as a possible cause of this clinical condition. There were no other signs of illness prior to the acute onset of dyspnoea to indicate $A$. vasorum as the cause in this dog.

Pneumothorax as a main presenting sign of angiostrongylosis has not been described previously, although it has been mentioned in one case series with the suggestion that the pneumothorax may have been secondary to the dog's dyspnoea (11). Pneumothorax can present bilaterally with a unilateral lesion as the mediastinum of most dogs is fenestrated, allowing free communication between the two pleural sacs (17). The bilateral presentation of pneumothorax in this case is therefore not surprising despite the unilateral nature of the lesion. Pulmonary bullae can develop from destruction, dilatation, and confluence of adjacent alveoli secondary to pulmonary pathology (18). Rupture results ultimately in pneumothorax as seen in our case.

Granulomatous pneumonia has been a consistent finding in dogs infected with

A. vasorum $(19,20)$. Rupture of vessels due to tissue and vascular damage induced by $A$. vasorum resulting in severe blood loss, haemopneumothorax, haemothorax and haemoabdomen have been described frequently in association with canine angiostrongylosis $(8,10,21)$. Interestingly, bleeding to the thoracic cavity was completely absent in this case.

Postoperative and 3-weeks-follow-up thoracic radiographs did not reveal an abnormal lung pattern, bronchial thickening or any signs of disseminated granulomatous pulmonary changes which could have indicated canine angiostrongylosis. Radiographic changes in dogs experimentally or naturally infected with $A$. vasorum commonly show a bronchial, alveolar and/or interstitial pattern and bronchial thickening mainly affecting the peripheral and dorso-caudal parts of the lung $(22,23)$. The duration of infection with $A$.

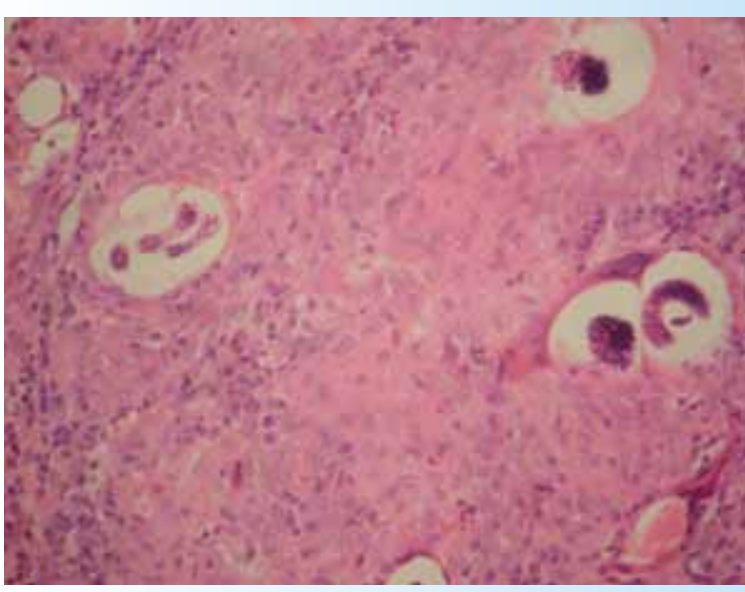

Figure 4. Lung histology, Hematoxylin and Eosin (HE) stain $x 400$. The coalescing granulomas centred on the larvae and embryos are illustrated including some heterokaryons. The lung parenchyma is collapsed, fibrotic and contains innumerable, often coalescing granulomata containing macrophages, eosinophils and multinucleate giant cells centred on parasitic larvae and eggs. No adult forms were identified. There is moderate, irregular muscular hypertrophy of the larger pulmonary vessels, and scattered haemosiderotic macrophages in the periarteriolar stroma in places. This is a chronic granulomatous pneumonia associated with immature stages of a lungworm. The concommitant vascular changes suggest that Angiostrongylus vasorum is the most likely cause. 
vasorum is unknown in this case, but the clinical and histologic findings indicate chronicity and while radiographic signs of pulmonary infiltrates may be masked during the partial lobar collapse of pneumothorax, they would have been expected in the post inflation, delayed studies.

The clinical pathological findings registered in this case report were unspecific which is often reported in dogs naturally infected with $A$. vasorum (24). Larvae were not identified on a direct faecal smear while subsequent Baermann analysis made a diagnosis of $A$. vasorum possi- ble. This report emphasises that it is important to consider $A$. vasorum as a cause of spontaneous pneumothorax secondary to underlying pulmonary pathology in dogs especially in areas endemic for this infection even in the absence of radiological changes supportive of an $A$. vasorum infection.

\section{None of the authors of this article has a} financial or personal relationship with other people or organisations that could inappropriately influence or bias the content of the paper.
Type I artikler i DVT omfatter både originalartikler (den første offentliggørelse af et resultat) og oversigtsartikler (videnskabelige artikler, der giver en samlet vurdering af den forskning, som findes om et bestemt emne). Type 1 artikler er fagfællebedømte, idet det videnskabelige indhold er vurderet og godkendt af en faglig redaktør inden publicering.

\section{Reference list}

1. Baillet, C.C. Strongle des vaisseaus et du coeur du chein Strongylus vasorum. N Dict Paract Med Vet. 1866. 8: 587-588

2. Bourdeau, P. Canine Angiostrongylus-Vasorum Infestation. Recueil de Medecine Veterinaire. 1993.169: 401-407

3. Brennan, S.F., Mc Carthy, G., McAllister, H., Bassett, H., and Jones, B.R. Clinical signs, diagnosis and treatment of three dogs with angiostrongylosis in Ireland. Irish Veterinary Journal. 2004. 57:103-109

4. Chapmann P.S., Boag, A.K., Guitian, J., and Boswood, A. Angiostrongylus vasorum infection in 23 dogs (1999-2002). Journal of Small Animal Practice. 2004. 45: 435-440 5. Morgan, E.R., Shaw, S.E., Brennan, S.F., De Waal, T.D., Jones, B.R., and Mulcahy, G. Angiostrongylus vasorum: a real heartbreaker. Trends in Parasitology. 2005. 21: 49-51 6 . Koch J., and Willesen, J.L. Canine pulmonary angiostrongylosis - an update. The Veterinary Journal. 2009. 179: 348-359

7. Wessmann, A., Lu, D., Lamb, C.R., Smyth, B., Mantis, P., Chandler, K., Boag, A., Cherubini, G.B., and Cappello, R. Brain and spinal cord haemorrhages associated with Angiostrongylus vasorum infection in four dogs. The Veterinary Record. 2006. 158: 858-863 8. Willesen, JL., Bjornvad, C.R., and Koch, J. Acute haemoabdomen associated with Angiostrongylus vasorum infection in a dog. Irish Veterinary Journal. 2008. 61: 591-593 9. Gredal, H., Willesen, J.L., Jensen, H.E., Nielsen, O.L., Kristensen, A.T., Koch, J., Kirk, R.K., Pors, S.E., Skerritt, G.C., and Berendt, $M$. Acute neurological signs as the predominant clinical manifestation in four dogs with Angiostrongylus vasorum infections in Den- mark. Acta Veterinaria Scandinavia. 2011. 53: 43 10. Sasanelli, M., Paradies, P., Otranto, D., Lia, R.P., and De Caprariis, D. Haemothorax associated with Angiostrongylus vasorum infection in a dog. Journal of Small Animal Practice. 2008. 49: 417-20

11. Martin, M., Ashton, G., Simpson, V.R., and Neal, C. Angiostrongylosis in Cornwall: clinical presentation of eight cases. Journal of Small Animal Practice. 1993. 34: 20-25

12. Burrows, C.F., O־Brien, J.A., and Biery, D.N Pneumothorax due to Filaroides osleri infestation in the dog. Journal of Small Animal Practice.

1972. 13: $613-8$

13. Busch, D.S., and Noxon, J.O. Pneumothorax in a dog infected with Dirofilaria immitis. Journal of American Veterinary Medical Association. 1992. 15: 1893

14. Sobel, K.E., Williams, J.E. Pneumothorax secondary to pulmonary thromboembolism in a dog. Journal of Veterinary Emergency and Critical Care. 2009. 19: 120-126

15. Morgan, E.R., Jefferies, R., Van Otterdijk, L., McEniry, R.B., Allen, F., Bakewell, M., and Shaw, S.E. Angiostrongylus vasorum infection in dogs: Presentation and risk factors. Veterinary Parasitology. 2010. 29: 255-61

16. Willesen, J.L., Kristensen, A.T., Jensen, A.L., Heine, J., and Koch, J. Efficacy and safety of imidacloprid/moxidectin spot-on solution and fenbendazole in the treatment of dogs naturally infected with Angiostronglyus vasorum (Baillet, 1866). Veterinary Parasitology. 2007. 147: 258264

17. AGUT, A. Radiology of the Mediastinum, Proceedings WSAVA 2002

18. Lipscomb, V.J., Hardie, R.J., and Dubielzig,

R.R. Spontaneous pneumothorax caused by pul- monary blebs and bullae in 12 dogs. Journal of American Animal Hospital Association. 2003. 39: 435-45

19. Bourque, A.C., Conboy, G., Miller, L.M., and Whitney, H. Pathological findings in dogs naturally infected with Angiostrongylus vasorum in Newfoundland and Labrador, Canada. Journal of Veterinary Diagnostic Investigation. 2008. 20: 11-20

20. Lepri, E., Veronesi, F., Traversa, D., Conti, M.B., Marchesi, M.C., Miglio, A., and Mandara, M.T. Disseminated angiostrongylosis with massive cardiac and cerebral involvement in a dog from Italy. Parasitology Research. 2011. 109: 505-8

21. Cury, M.C., and Lima, W.S. Rupture of femoral artery in a dog infected with Angiostrongylus vasorum. Veterinary Parasitology. 1996. 65: 313-5

22. Mahaffey, M.B., Losonsky, J.M., Prestwood, A.K., Mahaffey, E.A., and Lewis, R.E. Experimental canine angiostrongylosis: II.

Radiographic manifestations. Journal of the American Animal Hospital Association. 1981.17: 499-502

23. Boag, A.K., Lamb, C.R., Chapman, P.S., and Boswood, A. Radiographic findings in 16 dogs infected with Angiostrongylus vasorum. The Veterinary Record. 2004. 154: 426-430

24. Willesen, J.L., Jensen, A.L., Kristensen, A.T., and Koch, J. Haematological and biochemical changes in dogs naturally infected with Angiostronglyus vasorum before and after treatment. The Veterinary Journal. 2009. 180: 106-111 